\title{
Evapotranspiration of Cool-season Grasses Grown with Minimal Ma intenance
}

\author{
J.A. Doty ${ }^{1}$, W.S. Braunworth, Jr. ${ }^{2}$, S. Tan ${ }^{1}$, P.B. Lombard ${ }^{3}$, and \\ R.D. William ${ }^{3}$ \\ Department of Horticulture, Oregon State University, Corvallis, OR \\ 97331 “
}

Additional index words. Lolium perenne, Agrostis tenuis, Festuca arundinacea, neutron probe, soil water depletion

\begin{abstract}
Evapotranspiration (ET) of three perennial ryegrass (Lolium perenne L.) cultivars and one cultivar each of colonial bentgrass (Agrostis tenuis L.) and tall fescue (Festuca arundinacea L.) was measured in the field. Soil water depletion was measured with a neutron probe. Under minimal maintenance (i.e., no irrigation and infrequent mowing), ET was not significantly different for five perennial grasses. All grasses used more water than the bare-ground treatment. Soil water uptake was greatest in the upper soil layer $(O$ to $25 \mathrm{~cm})$ and decreased with depth. Few differences in water uptake were noted among grasses within each soil layer.
\end{abstract}

In western Oregon, some fruit and vines are not irrigated. Crops rely on stored soil moisture during the hot, dry periods. The Willamette Valley receives an average of 760 to $1020 \mathrm{~mm}$ of precipitation per year, most occurring in the fall through early summer. Orchard or vineyard alleys are typically maintained with sod cover or as bare ground using herbicides or a flail. Grass strips are recommended to reduce soil erosion, improve traffic conditions, and reduce soil compaction. In addition, sod extracts soil moisture and can reduce late-season vegetative growth on certain grape production sites (Vomocil, 1986). Disadvantages of using grass-cover crops include possible increased frost hazard and competition for soil nutrients and water (Vomocil, 1986). Perennial grass-cover crops might increase water stress during dry summer months by competing for stored soil moisture. Yield, vegetative growth, and fruit quality are correlated with soil moisture (Hardie and Considine, 1976; Van Reuyen et al., 1980).

Estimates of potential water use by coolseason grasses maintained as turf range between 2.4 to $7.5 \mathrm{~mm} \cdot \mathrm{day}^{-1}$ (Beard, 1973; Shearman, 1986). Vomocil (1986) noted that few studies determined water use by coolseason grasses under minimal maintenance, i.e., nonirrigated with three to four mowings per season. This information would be useful in selecting grasses for interplanting in vineyards or orchards. This study measured evapotranspiration (ET) of nonirrigated grasses,

\footnotetext{
Received for publication 20 Jan. 1989. Oregon Agricultural Experiment Station Technical Paper no. 8766 . The cost of publishing this paper was defrayed in part by the payment of page charges. Under postal regulations, this paper therefore must be hereby marked advertisement solely to indicate this fact.

'Graduate student.

${ }^{2}$ Assistant Professor.

${ }^{3}$ Professor.
}

evaporation from a bare soil, and computed reference ET of a well-watered grass sod.

Five perennial grasses, including 'Elks', 'Manhattan II', and 'Derby' perennial ryegrass (Lolium perenne), 'Olympic' tall fescue (Festuca arundinacea), and 'Highland' colonial bentgrass (Agrostis tenuis), were randomized with a bare-ground treatment in a complete-block design, replicated four times. Plots were prepared 6 July 1985 on a mixed, mesic Cumulic Ultic Hapeoxeroll soil (Chehalis silty clay loam) at the Lewis Brown Horticulture Farm located $5 \mathrm{~km}$ east of Corvallis. The facility is at $44.6^{\circ} \mathrm{N}$ latitude, $123.2^{\circ} \mathrm{W}$ longitude, and $69 \mathrm{~m}$ elevation.

Seed of each species was sown 16 July 1985 at $22.4 \mathrm{~kg} \cdot \mathrm{ha}^{-1}$ in $4.6 \times 4.6-\mathrm{m}$ plots. Bare-ground plots were established using napropamide plus simazine followed with bromoxynil and glyphosate. Plots were irrigated four times daily for 2 weeks after planting to encourage uniform germination and they were fertilized with urea and $15 \mathrm{~N}-15 \mathrm{P}-15 \mathrm{~K}$ at $20 \mathrm{~kg} \mathrm{~N} / \mathrm{ha}$. Selective broadleaf herbicides (2,4-D, mecoprop, and dicamba) were applied to grass plots to develop a pure stand of the desired species. During the 3-year monitoring period, turf was mowed every 4 weeks at 3-cm height April through June. Additional irrigation or fertilization was omitted following establishment in 1986.

Access tubes made of 5-cm diameter aluminum pipe were installed to a depth of 137 $\mathrm{cm}$ to measure soil water content with a neutron meter hydroprobe moisture depth gauge (model 503DR, Campbell Pacific Nuclear, Pacheco, Calif.). Moisture readings at five depths ( 0 to 15,15 to 25,25 to 35,35 to 75 , and 75 to $105 \mathrm{~cm}$ ) were recorded every 7 to 14 days from 14 Apr. to 28 July in 1986 , 15 Apr. to 27 Aug. in 1987, and from 10 May to 23 Aug. in 1988. Grass ET and evaporation were determined by three computer programs written in Fortran to analyze neutron probe data (Cuenca, 1988). One program establishes the data files, the second relates soil moisture content with depth and time, and the third produces a hydrologic balance and estimated ET. Two calibration constants of soil moisture content with probe readings were developed at 0 to $15 \mathrm{~cm}$ and 15 to $105 \mathrm{~cm}$ soil horizons (Braunworth and Mack, 1987).

Seasonal ET was partitioned into water uptake from four soil layers ( 0 to 25,25 to $35,35$ to 75,75 to $105 \mathrm{~cm})$. Soil water uptake was calculated for standard $10-\mathrm{cm}$ layers, since field data represented a range of layers from 10 to $40 \mathrm{~cm}$.

Weather data for 12-hr periods were obtained about $1 \mathrm{~km}$ north of the experimental site. Cuenca and Martinez (unpublished data) selected data and computed reference crop ET for a well-watered grass according to the Food and Agriculture Organization Modified Penman equation (Doorenbos and Pruitt, 1977).

Seasonal ET averaged 2.5, 1.5, and 1.8 $\mathrm{mm} \cdot$ day $^{-1}$ in 1986, 1987, and 1988, respectively, with no significant differences in the seasonal ET rates among the five grass species (Table 1). In all years, seasonal water use by bare ground was less than that by the grass areas.

Our seasonal computed ET (Table 1) was lower than those reported by Beard (1973) or Shearman (1986). In those studies, ET was monitored under well-watered conditions, whereas our lower ET rates were likely due to drier soil condition and minimum fertilizer. Although Feldhake et al. (1984) evaluated grass quality with deficit irrigation, they failed to mention the effect on ET.

The similarity in grass soil water uptake is in contrast to the different growth characteristics among the species that were expected to affect ET (Troughton, 1957; Beard, 1973). Deep-rooted grass species, such as $F$. arundinacea, were expected to use more water than shallow-rooted grasses, such as A. tenuis, because deep roots could allow plants to transpire by extracting soil water stored deeper in the profile (Sheffer et al., 1987). In 1987, L. perenne and A. tenuis were brown and dry by 17 June, while $F$. arundinacea remained green until mid-August. The apparent variation in growth habits, however, did not result in significant differences in seasonal ET rates.

Monthly ET values for the five grass covers were similar but greater than the evaporation values for bare ground in most months. In June 1987 and July 1988, monthly ET rates were similar among all six treatments, likely due to low rainfall and low soil water content in all treatments, which would tend to restrict ET (Tables 1 and 2). However, in August 1987 and 1988, bare-ground plots exhibited significantly greater evaporation than the grasses. Periodic rainfall, coupled with warm temperatures, increased evaporation on bare ground, whereas grasses appeared to hold the moisture.

In general, grass ET values as a percentage of a reference crop ET were higher in May than later, due to greater precipitation and greater soil moisture levels. ET rates of grasses during July 1987 increased over those 
Table 1. Mean monthly and seasonal evapotranspiration (ET) of bare ground and five grass covers, Corvallis, Ore.

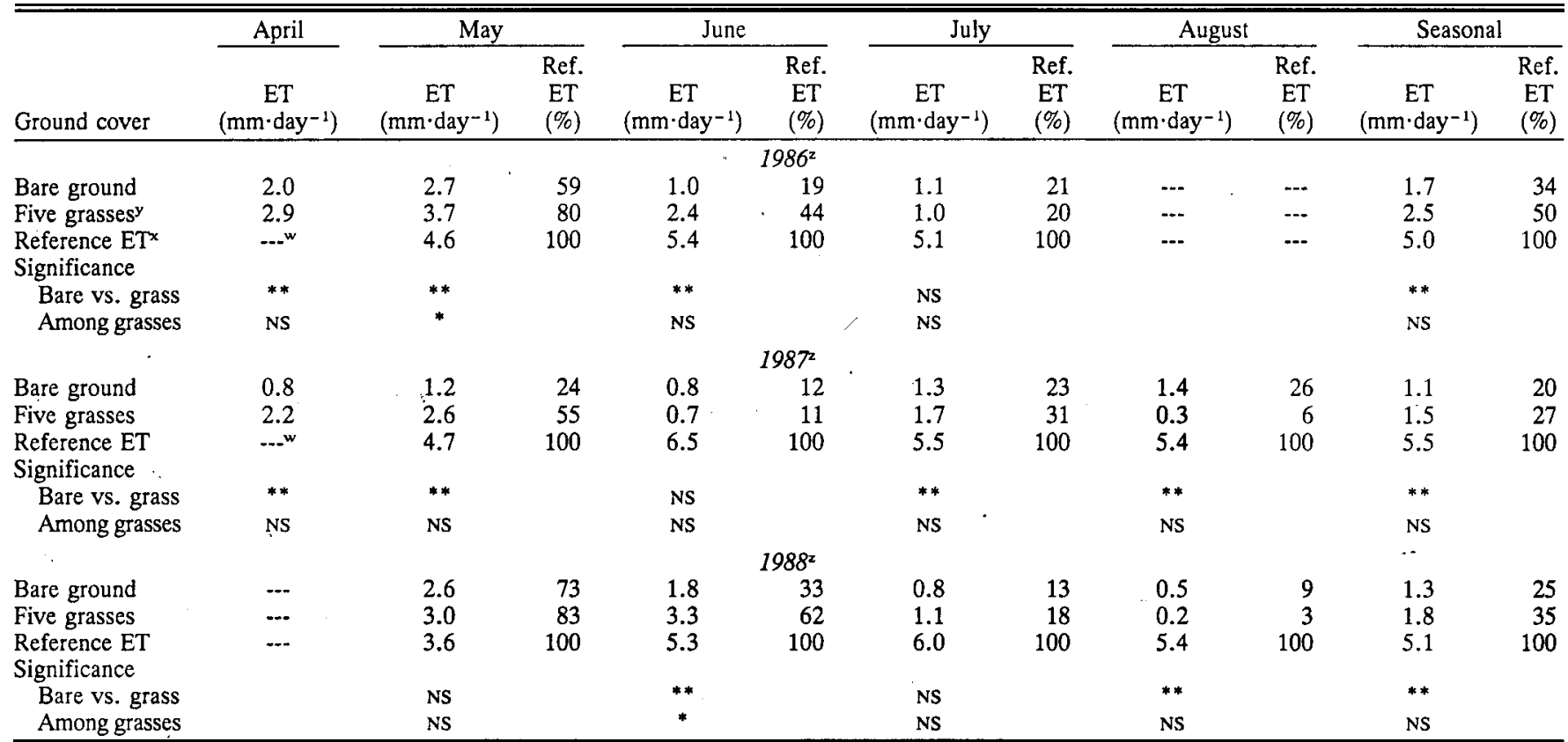

${ }^{2}$ Season included 105 days between 14 Apr. and 28 July 1986; 133 days between 15 Apr. and 27 Aug. 1987; and 105 days between 10 May and 23 Aug. 1988.

'Grass covers: 'Highland' A. tenuis, 'Olympic' F. arundinacea, 'Manhattan II' L. perenne, 'Elka' L. perenne, 'Derby' L. perenne.

${ }^{x}$ Reference ET was computed with the FAO-modified Penman equation by R. Cuenca and A. Martinez-Cobb (unpublished data).

"Data unavailable.

NS, $* * *$ Nonsignificant or significant at $P=0.05$ or 0.01 , respectively, by $\mathrm{F}$ test. Data are means of four observations for bare ground and each grass cover.

of June due to rainfall (Tables 1 and 2). Although grasses lack apparent growth due to water stress in late summer, rainfall events can increase ET rates due to increased evaporation from the soil. The reference crop ET ranged from $\approx 90 \%$ in May 1988 to $\leq 5 \%$ later in the season. Although the grasses used more water than the bare-ground treatment, they used less water than a well-watered grass, thereby supporting the concept of less water use when grass strips are alternated with crop rows and drip-irrigated.

Table 2. Monthly precipitation for 3 years during study periods at Corvallis, Ore.

\begin{tabular}{lrrr}
\hline \hline & \multicolumn{3}{c}{ Rainfall $(\mathrm{mm})$} \\
\cline { 2 - 4 } Month & 1986 & 1987 & 1988 \\
\hline April & 34 & 6 & 86 \\
May & 67 & 22 & 49 \\
June & 7 & 5 & 1 \\
July & 19 & 58 & 1 \\
August & 0 & 0 & 0 \\
Total & 127 & 91 & 137 \\
\hline
\end{tabular}

Soil water uptake decreased with depth (Table 3). This' result was expected, since most grass roots are near the soil surface and rainfall fills the uppermost soil layers first and then may be lost by ET. The water loss rates for bare ground were equal to or lower than those for grass cover treatments. Few differences in water uptake were noted among grasses within each soil layer. Although $A$. tenuis and $F$. arundinacea had the greatest root mass below $50 \mathrm{~cm}$ (Doty, 1988), water uptake rates were similar for the grasses in the 35 to 75 and 75 to $105 \mathrm{~cm}$ soil horizons. Grass soil water uptake rates from the 35- to $75-\mathrm{cm}$ soil horizon exceeded evaporation from bare ground.

Our study suggests that ET of these three cool-season grass species grown under minimal maintenance was not an important characteristic to consider when selecting a grass as a cover crop. However, management practices, such as mowing and fertilization, have been shown to influence ET. (Sullivan and Sprague, 1943; Biran et al., 1981; Feld- hake et al., 1983).

Under minimal maintenance, including lack of irrigation, ET of these cool-season grasses was similar. Grass water use in western Oregon peaks in late spring or early summer and declines as soil water is depleted through the season. Other characteristics, such as establishment rate and wear tolerance may be more important considerations than water use when choosing a grass species as a cover crop in a low-maintenance system.

\section{Literature Cited}

Beard, J.B. 1973. Turfgrass: Science and culture. Prentice-Hall, Englewood Cliffs, N.J.

Biran, I., B. Bravado, I. Bushkin-Harav, and E. Rawlitz. 1981. Water consumption and growing rate of 11 turf grasses as affected by mowing height, irrigation frequency, and soil moisture. Agron. J. 73:85-90.

Braunworth, W. S., Jr. and H.J. Mack. 1987. Evapotranspiration and yield comparisons among soil water balance and climate based equations for irrigation scheduling of sweet corn. Agron. J. 79:837-841.

Table 3. Contribution of five soil layers to total seasonal soil water uptake of bare ground and five grass covers from 1986-1988 at Corvallis, Ore.

\begin{tabular}{|c|c|c|c|c|c|c|c|c|c|c|c|c|}
\hline \multirow[b]{4}{*}{ Ground cover } & \multicolumn{12}{|c|}{ Soil water uptake $\left(\mathrm{mm} \cdot \text { day }^{-1}\right)^{2}$} \\
\hline & \multicolumn{12}{|c|}{ Soil layer $(\mathrm{cm})$} \\
\hline & \multicolumn{4}{|c|}{1986} & \multicolumn{4}{|c|}{1987} & \multicolumn{4}{|c|}{1988} \\
\hline & $0-25$ & $25-35$ & $35-75$ & $75-105$ & $0-25$ & $25-35$ & $35-75$ & $75-105$ & $0-25$ & $25-35$ & $35-75$ & $75-105$ \\
\hline Bare ground & 0.57 & 0.05 & 0.04 & 0.01 & 0.36 & 0.05 & 0.03 & 0.01 & 0.37 & 0.11 & 0.05 & 0.03 \\
\hline Five grasses ${ }^{y}$ & 0.67 & 0.14 & 0.12 & 0.06 & 0.38 & 0.09 & 0.07 & 0.04 & 0.39 & 0.15 & 0.11 & 0.07 \\
\hline \multicolumn{13}{|l|}{ Significance } \\
\hline Bare vs. grass & $* *$ & $* *$ & $* *$ & $* *$ & $* *$ & ** & $* *$ & NS & NS & $* *$ & $* *$ & NS \\
\hline Among grasses & NS & NS & NS & NS & NS & NS & NS & NS & NS & NS & $*$ & NS \\
\hline
\end{tabular}

${ }^{7}$ Soil water uptake rates based on a 10-cm soil depth at the five layers for comparison; data are means of 4 observations of bare ground and each grass. 'Grass covers: 'Highland' A. tenuis, 'Olympic' F. arundinacea, 'Manhattan II' L perenne, 'Elks' L perenne, 'Derby' L. perenne.

$\mathrm{NS}, * * *$ Nonsignificant or significant at $P=0.05$ or 0.01 , respectively, by $\mathrm{F}$ test. 
Cuenca, R.H. 1988. Hydrologic balance model using neutron probe data. J. hr. and Drainage Eng. 114(4):644-662.

Doorenbos, J. and W.O. Pruitt. 1977. Guidelines for predicting crop water requirements. FAO Irr. and Drainage Paper 24. FAO, Rome.

Doty, J.A. 1988. Water use of cool season grasses and their effect on grapevine (Vitis vinifera) growth and development. M.S. Thesis, Oregon State Univ.

Feldhake, C. M., R.E. Danielson, and J.D. Butler. 1983. Turfgrass ET. I. Factors influencing rate in urban environments. Agron. J. 75:824830 .
Feldhake, C. M., R.E. Danielson, and J.D. Butler. 1984. Turfgrass ET. H. Responses to deficit irrigation. Agron. J. 76:85-89.

Hardie, W. J. and J. Considine. 1976. Responses of grape to water deficits and stress in particula stages of development. Amer. J. Enol. Viticult. 27:55-61.

Shearman, R.C. 1986. Kentucky bluegrass cultivar ET rates. HortScience 21:455-457.

Sheffer, K. M., J.H. Dunn, and D.D. Minner. 1987. Summer drought response and rooting depth of three cool season turfgrasses. HortScience 22:296-297.

Sullivan, J.T. and V.G. Sprague. 1943. Compo- sition of the roots and stubble of perennial ryegrass following partial defoliation. Plant Physiol. 18:656-670.

Troughton, A. 1957. The underground organs of herbage grasses. Academic, New York.

Van Reuyen, F. C., H.W. Web, and 1. Levin. 1980. The response of grapes to a manipulation of the soil plant atmosphere continuum. I. Growth. yield, and quality response. Agrochemophysica 12:59-68.

Vomocil, J. 1986. Effects of cover crops on availability of water to grapevines in the Willamette Valley in 1985. Wine Advisory Bd. Rpt. 3:811.
HorTSCIENCE 25(5):531-533. 1990

\section{Effects of Morphactin and DCPTA on Stem Growth and Bioinduction of Rubber in Guayule}

\author{
D.A. Dierig and R.A. Backhaus ${ }^{1}$ \\ U.S. Water Conservation Laboratory, U.S. Department of Agriculture, \\ Agricultural Research Service, Phoenix, AZ 85040
}

Additional index words. Parthenium argentatum, bioregulator, chloroflurenol, chloroflurecol, growth regulators

\begin{abstract}
Morphactin applied to stems of guayule (Parthenium argentatum Gray) at rates of 1000 and $5000 \mathrm{ppm}$ caused significant increases in stem diameter over nontreated controls after 120 days. However, rubber content remained unchanged. Additional treatment with DCPTA did not stimulate rubber accumulation in the morphactintreated plants. Morphactin treatments also caused a decrease in plant dry weight. Morphactin and DCPTA in combination appeared to have a negative, synergistic effect on plant growth. Lack of rubber accumulation in morphactin-treated plants was attributed to disorganized, convoluted, vascular cells within the cortical tissue, which is the primary site of rubber accumulation. Chemical names used: methyl-2-chloro-9. hydroxy-fluorene-9-carboxylate (morphactin); 2-(3,4-dichlorophenoxy)-triethylamine (DCPTA).
\end{abstract}

Guayule is a potential source of natural rubber in arid regions of the world. Unlike the rubber tree (Hevea brasiliensis Mull. Arg.), where rubber forms in laticifers, rubber formation in guayule takes place in parenchyma cells of stem cortical tissue (Artschwager, 1943). Maximum rubber yield is the result of a large bark : wood ratio (Artschwager, 1945; Estilai, 1985; Healey et al., 1986). Thus, if the bark, or potential rubber-bearing cells, could be increased in proportion to the wood, or nonrubber-bearing cells, rubber accumulation could possibly be increased.

Received for publication 3 Jan. 1989. From a thesis submitted by D.A.D in partial fulfillment of the requirements for the MS. Trade names and company names are included for the benefit of the reader and do not imply any endorsement or preferential treatment of the product listed by either the authors or the USDA. The cost of publishing this paper was defrayed in part by the payment of page charges. Under postal regulations, this paper therefore must be hereby marked advertisement solely to indicate this fact.

'Professor, Dept. of Botany, Arizona State Univ., Tempe, AZ 85281.
Morphactin has been shown to cause localized swelling of cortex tissue in Monterey pine (Pinus radiata D. Don) when applied topically to the bark (Doss et al., 1977). This bark-banding treatment was originally used as a systemic means of introducing morphactin for growth inhibition in pine and other species (Backhaus et al., 1976). However, the compound caused undesirable swelling due to increased cambial and peridermal activity (Doss et al., 1977).

Rubber synthesis in guayule was reported to be enhanced by treating plants with DCPTA (Yokoyama, 1977; Hayman et al., 1987). Therefore, the purpose of our study was to use morphactin to induce swelling in stems of guayule to increase the bark : wood ratio in an attempt to increase the rubber-forming capacity of the stems. The effect of DCPTA was then tested, alone or following various morphactin treatments, to measure the effectiveness of increasing rubber accumulation in guayule.

The study was conducted in 1982 at the Arizona State Univ. Farm Laboratory, Tempe. Plants were propagated from a bulk seed collection from the guayule breeding program of G. Hansen at the Los Angeles State and county Arboretum, Los Angeles. Plants were transplanted into the field 'at $1 \times 0.36-\mathrm{m}$ spacing and flood irrigated about six times per year. After 2 years of growth, height and stem diameter measurements were taken at 20-day intervals, beginning 1 July, and continued for 120 days. Morphactin was applied 9 July and DCPTA on 30 Sept. Increases in growth over this interval were calculated as a percentage of the initial measurement. Stem diameters were obtained with a micrometer by averaging the widest and narrowest values of the stem at ground level. Plants were harvested after 14 weeks to determine dry weight and rubber content.

To test for enhancement of rubber-bearing cells, six treatments (all per plant) were used: a) nontreated control, b) $1000 \mathrm{ppm}$ morphactin, c) $5000 \mathrm{ppm}$ morphactin, d) 400 ppm DCPTA, e) 1000 ppm morphactin followed by $400 \mathrm{ppm}$ DCPTA, and f) $5000 \mathrm{ppm}$ morphactin followed by $400 \mathrm{ppm}$ DCPTA. Morphactin treatments preceded the DCPTA treatments by 83 days to allow sufficient time for increasing stem diameters. Morphactin solutions were applied according (o the procedures of Backhaus et al. (1976). The compound was supplied from a commercial formulation (Maintain CF 125-U.S. Borax) containing $12.5 \%$ morphactin that was then formulated in a phytobland oil and applied to the bark. Dosage was varied by adjusting the concentration of Maintain CF-125 in culinary Wesson corn oil to make either a 1000or 5000-ppm solution. The morphactin barkbanding solution was prepared by mixing 4 $\mathrm{ml}(5000 \mathrm{ppm})$ or $0.8 \mathrm{ml}(1000 \mathrm{ppm})$ of CF125 with $4 \mathrm{ml}$ of SPAN 80, an emulsifier, and adjusting each to $100 \mathrm{ml}$ with Wesson oil. A plant received $10 \mathrm{ml}$ of this solution applied with a paint brush along the length of the main stem. Shallow cuts through the suberin layer were made before the morphactin application to ensure solution penetration.

DCPTA was obtained from H. Yokayama, USDA/ARS, Pasadena, Calif., and was applied as a foliar spray. Each plant received $25 \mathrm{ml}$ of a 400-ppm solution (Hayman et al., 1987) on 30 Sept., 83 days after morphactin application. Plants were harvested 36 days after DCPTA applications, dried at 50C in a forced-air oven for $48 \mathrm{hr}$, and weighed. Leaves and peduncles were removed before 